\title{
Critical Thinking of Extrovert Girls in Problem Solving
}

\author{
Marlinda Indah Eka Budiarti \\ Mathematics Education Department \\ Universitas Muhammadiyah Sorong \\ Sorong, Indonesia \\ indah.eka43@gmail.com
}

\author{
Ruslan \\ English Education Department \\ Universitas Muhammadiyah Sorong \\ Sorong, Indonesia \\ ruslanruse89@gmail.com
}

\begin{abstract}
- the purpose of this research is to know the ability of critical thinking of students in problem solving based on gender, personality and critical thinking in solving the problem. This research used qualitative descriptive that conducted at SMP Muhammadiyah 8 in Batu, and the students of VII grade as subject and the object is critical thinking skill in problem solving. It used Eysenck Personality inventory-A (EPI-A) test for the instrument which conducted in the first meeting to all students, problem solving test was given to 6 extrovert girls, and interview. Problem solving strategy used to know critical thinking skill by giving personality EPI-A test in the first meeting on students of VII grades to find respondents 6 extrovert girls. After finding the respondents, the next step is giving problem solving test. The researcher interviewed the result of respondents. Findings showed that: 1) High critical thinking of extrovert girls were not success in strategy step, only in alternative solution 2) Moderate critical thinking of extrovert girls were not success and inference step was success in writing skill, but when they were asked to explain it, they were not able to do it so they did not pass the strategy step. 3) Low critical thinking of extrovert girls was not success for inference and strategy step.
\end{abstract}

\section{Keywords - Critical Thinking Skill, Problem Solving, Extrovert Girls.}

\section{INTRODUCTION}

One of the aims of learning mathematic is to make the students think critically. Critical thinking cannot be developed by physical development of human being. It must be trained by stimulus giving which encourages students to think critically. School is one of educational institutions which have responsibility to develop critical thinking skill.

[3], there are several competences which related to critical thinking, are 1) Develop, use and apply information about environment logically, critically and creatively, 2) Present the way of thinking logically, critically and creatively, also innovatively. 3) Present the problem solving way, 4) Present the strong desire and realize the potency, 5) Present the independent learning ability. Critical thinking skill could motivate students to acquire and respond the question given in order to slove the problem.

Developing the critical thinking is important for students to explore mathematic ideas which used in problem solving [7;6] Problem solving is a process to solve the problem[11]. It is essential to do by mathematic's teacher since by giving problem solving mathematic exercise; students could be analytic and critical in deciding a decision and also could applicate it in other situation.

In the fact, based on the research findings which showed the low of critical thinking students $[12 ; 8]$. It is in line with TIMSS Indonesia students are low in answering the questions which related to justification and proofing, problem solving needs mathematical reasoning, finding generalization and conjecture, then the correlation between the data and the fact.

Ability to solve mathematic problem is affected by several factors, both internal and external. Internal factor is intelligence, motivation, readability, talent and mathematic skill also gender [8]. It is reinforced by a research entitled Gender Differences in Problem Solving affected to complex variables including biologist, psychology, and environment [13;5].

[1] stated that: "there are differences of cognitive ability between male and female. The males are more rational, has enthusiasm directed to the things that intellect, abstract, such that they are better in logical thinking and more critical" . It shows that there are the differences between boys' cognitive and girls' co gnitive. Boys are more logical, and have enthusiasm which leads to intellectual, abstract, therefore, they are better in thinking logically and critically. It showed that the differences of gender also will be different in personality, here the researcher want to know the ability of critical thinking in solving problem based on gender and personality.

Several researches related to critical thinking [2] stated that there is significant gender distinction on Mathematic performance test. Critical thinking ability is effective way to improve students' understanding about mathematic. Therefore, it is recommended to teach mathematic in senior high school, so the teacher could apply critical thinking skill in curriculum which able to improve students' performance on mathematic and it is in line with [10] stated that students with critical thinking will be able to think critically as students require all step of critical thinking when solving the problem. [4] stated that there is the 
differences of thinking process in solving problem based on gender and introvert and extrovert personality.

Therefore, the researcher try to conduct this research focused on the analysis of critical thinking skill in solving mathematic problem based on personality and gender. The differences between this research and previous research is in critical thinking skill

\section{Problem Statement}

Based on background of study, statement of problems as follow:

How does the students critical thinking of extrovert girls in solving the problem?

\section{Methodology}

This research was used descriptive, and used qualitative approach. Subject of the research was conducted six students of junior high school that has criteria as two girls who introvert personality that use questionnaire of personality type based on question form adapted by EPI
(Eysenck Personality Inventory) test. To removal method the subject of the research was eight students of junior high school did choose has criteria, tested in problem solving question to know how to the process in problem solving students, then continued interview to know how the students' critical thinking skill.

\section{RESULT AND DiSCUSSION}

Based on findings of the research, has getting six participants is performed in the following table.

TABLE. I. CRITICAL THINKING SKILL OF EXTROVERT GIRLS

\begin{tabular}{|c|c|c|c|c|}
\hline Name & $\begin{array}{c}\text { Reading and } \\
\text { Thinking }\end{array}$ & Exploring and Planning & Choose Strategy and Find Answer & Reflecting and Developing \\
\hline IT & $\begin{array}{l}\text { Able to answer } \\
\text { the known, } \\
\text { question asked } \\
\text { clearly and } \\
\text { correctly. }\end{array}$ & $\begin{array}{l}\text { a. able to explore the fact in } \\
\text { the task. } \\
\text { b. had explained the concept } \\
\text { that would be used in } \\
\text { completing the task by } \\
\text { using own language }\end{array}$ & $\begin{array}{l}\text { a. had used relevant information or the } \\
\text { knowledge to answer the question. } \\
\text { b. able to explain the relationship each } \\
\text { information } \\
\text { c. able to decide the step to answer the } \\
\text { task. }\end{array}$ & $\begin{array}{l}\text { a. had found alternative solution to } \\
\text { answer the task. } \\
\text { b. had evaluated all step in completing } \\
\text { the task. } \\
\text { c.did not explain the completion step } \\
\text { yet. }\end{array}$ \\
\hline NR & $\begin{array}{l}\text { Able to answer } \\
\text { the known, } \\
\text { question asked } \\
\text { clearly and } \\
\text { correctly }\end{array}$ & $\begin{array}{l}\text { a. had explored the fact in } \\
\text { the task. } \\
\text { b. had explained the concept } \\
\text { that would be used in } \\
\text { completing the task by } \\
\text { using own language }\end{array}$ & $\begin{array}{l}\text { a. had used relevant information or the } \\
\text { knowledge to answer the question. } \\
\text { b. had explained the relationship each } \\
\text { information } \\
\text { c. had decided the step to answer the task. }\end{array}$ & $\begin{array}{l}\text { a. had found alternative solution to } \\
\text { answer the task. } \\
\text { b. had evaluated all step in completing } \\
\text { the task. } \\
\text { c. did not explain the completion } \\
\text { step yet. }\end{array}$ \\
\hline NH & $\begin{array}{l}\text { Able to answer } \\
\text { the known, } \\
\text { question asked } \\
\text { clearly and } \\
\text { correctly }\end{array}$ & $\begin{array}{l}\text { a. able to explore the fact in } \\
\text { the task. } \\
\text { b. able to explain the concept } \\
\text { that would be used in } \\
\text { completing the task by } \\
\text { using own language }\end{array}$ & $\begin{array}{l}\text { a. could not use relevant information or } \\
\text { the knowledge to answer the question. } \\
\text { b. could not explain the relationship each } \\
\text { information } \\
\text { c. could not decide the step to answer the } \\
\text { task yet. }\end{array}$ & $\begin{array}{l}\text { a. Did not find alternative solution to } \\
\text { answer the task yet. } \\
\text { b. did not evaluate all step in } \\
\text { completing the task yet. } \\
\text { c. Did not explain the completion } \\
\text { step yet. }\end{array}$ \\
\hline DE & $\begin{array}{l}\text { Had able to } \\
\text { answer the } \\
\text { known, question } \\
\text { asked clearly and } \\
\text { correctly }\end{array}$ & $\begin{array}{l}\text { a. had explored the fact in } \\
\text { the task. } \\
\text { b. had explained the concept } \\
\text { that would be used in } \\
\text { completing the task by } \\
\text { using own language }\end{array}$ & $\begin{array}{l}\text { a. able to use relevant information or the } \\
\text { a. knowledge to answer the question. } \\
\text { b. could not explain the relationship each } \\
\text { information yet } \\
\text { c. could not decide the step to answer the } \\
\text { task yet. }\end{array}$ & $\begin{array}{l}\text { a. Did not find alternative solution to } \\
\text { answer the task yet. } \\
\text { b. did not evaluate all step in } \\
\text { completing the task yet. } \\
\text { c. Did not explain the completion } \\
\text { step yet. }\end{array}$ \\
\hline WA & $\begin{array}{l}\text { Able to answer } \\
\text { the known, } \\
\text { question asked } \\
\text { clearly and } \\
\text { correctly }\end{array}$ & $\begin{array}{l}\text { a. could not explore the fact } \\
\text { in the task. } \\
\text { b. could not explain the } \\
\text { concept that would be used } \\
\text { in completing the task by } \\
\text { using own language }\end{array}$ & $\begin{array}{l}\text { a. Could not use relevant information or } \\
\text { the knowledge to answer the question. } \\
\text { b. could not explain the relationship each } \\
\text { information. } \\
\text { c. could not decide the step to answer the } \\
\text { task. }\end{array}$ & $\begin{array}{l}\text { a. Did not find alternative solution to } \\
\text { answer the task yet. } \\
\text { b. did not evaluate all step in } \\
\text { completing the task yet. } \\
\text { c. Did not explain the completion } \\
\text { step yet. }\end{array}$ \\
\hline $\mathbf{A F}$ & $\begin{array}{l}\text { Was not able to } \\
\text { answer the } \\
\text { known, question } \\
\text { asked clearly and } \\
\text { correctly }\end{array}$ & $\begin{array}{l}\text { a. able to explore the fact in } \\
\text { the task. } \\
\text { b. could not explain the } \\
\text { concept that would be used } \\
\text { in completing the task by } \\
\text { using own language }\end{array}$ & $\begin{array}{l}\text { a. Could not use relevant information or } \\
\text { the knowledge to answer the question. } \\
\text { b. could not explain the relationship each } \\
\text { information. } \\
\text { c. could not decide the step to answer the } \\
\text { task. }\end{array}$ & $\begin{array}{l}\text { a. Did not find alternative solution to } \\
\text { answer the task. } \\
\text { b. did not evaluate all step in } \\
\text { completing the task. } \\
\text { c. Did not explain the completion step. }\end{array}$ \\
\hline
\end{tabular}


Based on findings from extrovert girls were: a) high ability was IT with the result was 86,67 and NR with the result was 71,66 ; b) medium ability was $\mathrm{NH}$ with the result was 70 and DE with the result was 60; c) low ability was WA with the result was 43,3 and AF with the result was 40,33.

Based on both findings above, it obtained the findings that extrovert girl with critical thinking which categorized on high ability, they were able to pass all the steps. It was caused that the boy was on 12 years old tend to the lack of motivation on developing mathematic interest. Since boy was on labil situation and more focused on game such as video game, and online game. It was stated in line with the result of research about gender in problem solving affected on many complex variables including biologist, psychologist, and environment [13;5]

Based on findings of extrovert girls critical thinking were: a) high ability was CA and FA; b) medium ability was $\mathrm{AR}$ and $\mathrm{NU}$; c) Low ability was $\mathrm{HN}$ and $\mathrm{ZA}$. The findings of introvert critical thinking were: a) high ability was DP with the result was 78,3 and $\mathrm{OM}$ with the result was 76,69 ; b) medium ability was CD with the result was 63,3 and MD with the result was 65,0 ; c.) low ability was FA with the result was 46,6 and MA with the result 46,6. While the findings of introvert girls critical thinking were: a) high ability was CA with the result was 78,3 and FA with the result was 86,$6 ;$ b) medium ability was AR with the result was 61,67 and NU with the result was 60 ; c) low ability was $\mathrm{HN}$ with the result was 53,3 and ZA with the result was 48,33 . It was stated in line with Sabrina's (2013) stated that boy was more open minded than girl so he was more detail and able to give reason with the knowledge.

If it was viewed from personality, extrovert girl and extrovert boys were more doing action before thinking the effect which lead to hurry situation to give answer, therefore it often made mistake in completing the task. While, introvert boy and introvert girl have good memory, they were typical of thinker in handling mathematic problem in detail. It was contrast with finding of Hasanah' research. [4] stated that extrovert boy and extrovert girl were more detail than introvert girl and introvert boy.

\section{CONCLUSION}

Based on the data analysis which presented in the previous chapter, it could be concluded as follows:

1. High critical thinking skill of extrovert girls passed on clarification, assessment, inference step successfully. While they only gave alternative solution on strategy step.

2. Medium critical thinking skill of extrovert girls passed on clarification and assessment. While on inference students were in writing skill, but they were not able to explain the task.

3. Low critical thinking skill of extrovert girls passed on clarification and assessment. While they failed on inference and strategy step.

\section{REFERENCE}

[1] Arends. Learning to Teach-Translated by Soetjipto. Students Reference:Yogyakarta. (2008).

[2] Chukwuyenum. Impact of Critical thinking on Performance in Mathematics among Senior Secondary School Students in Lagos State. IOSR Journal of Research \& Method in Education (IOSR-JRME) $e$ ISSN: 2320-7388,p-ISSN: 2320-737X Volume 3, Issue 5. 2013.

[3] Goverments Rule. No 23. 2006. About Graduate Standard.

[4] Hasanah,N. Mardiyana, M, Sutrima, S. Analysis Students Thinking Process in Mathematic's Problem Solving Evaluated by Extrovert-Introvert Personality Type and Gender. Journal of Mathematic Learning Vol 1, No 4. (2013).

[5] Marcia, etc. Cross-National Patterns of Gender Differences in Mathematics: A Meta-Analysis. American

Psychological Association 2010, Vol. 136, No. 1. (2010).

[6] Muhassanah, N, et al. Analysis Students Geometri Skill in Geometry's Problem Solving Based Thinking Level of Van Hiele. Journal of Mathematic Learning Elektronic. Vol. 2, No. 1. (2014).

[7] NCTM. A Research on Geometry Problem Solving Strategies Used By Elementary Mathematics Teacher Candidate. (2010).

[8] Peter, E. Critical Thinking: Essence For Teaching Mathematics And Mathematics Problem Solving Skills. African Journal of Mathematics and Computer Science Research Vol. 5(3), pp. 39-43, 9M. Young, The Technical Writer's Handbook. Mill Valley, CA: University Science, 1989. (2012).

[9] Rasiman. Leveling of Students Critical Ability In Solving Mathematics Problem Based On Gender Differences. International Jurnal of Education And Research Volume 3 No 4. (2015).

[10] Ramalisa, Yelli. Critical Students Process of Senior High School of Thinking Personality Type in Problem Solving. Edumatica Volume 3 No 1. (2013).

[11] Siswono, T.Y.E. Model of Mathematic Learning Based on Submission and Problem Solving to Develop Creatif Thinking Skill. Surabaya: Unipress. (2008).

[12] Suryadi, D. Using Indirect Learning Approach With Direct and Indirect Aliance Approach to Develop Mathematical Thinking Skill at Junior High School Students. Dessertasi UPI. (2005).

[13] Zheng zhu. Gender differences in mathematical problem solving patterns: A review of literature .International Education Journal, 2007, 8(2), 187-203. ISSN 1443-1475 ()

2007 Shannon Research Press. 2007.http://iej.com.au 